\title{
Strategi Belajar Sq3r (Survey, Question, Read, Recite, Review) dalam Upaya Peningkatan Pemahaman Bacaan Siswa
}

Sobri

How to cite : Sobri., 2018. Strategi Belajar Sq3r (Survey, Question, Read, Recite, Review) dalam Upaya Peningkatan Pemahaman Bacaan Siswa . Journal of Language Learning and Research. 1(1). 1-11. https://doi.org/10.22236/jollar.v1i1.1242

To link to this article: https://doi.org/10.22236/jollar.v1i1.1242

(C2021. The Author(s). This open access article is distributed under a Creative Commons

Attribution (CC BY-SA) 4.0 license.

Published Online on 11 Maret 2020




\title{
Strategi Belajar Sq3r (Survey, Question, Read, Recite, Review) dalam Upaya Peningkatan Pemahaman Bacaan Siswa
}

\section{Sobri}

\begin{abstract}
Abstrak
Penelitian ini bertujuan ingin mengetahui efektivitas metode SQ3R (Survey, Question, Read, Recite, Review) dalam meningkatkan pemahaman bacaan bahasa Indonesia siswa. Metode penelitian ini menggunakan pendekatan kualitatif, dilakukan dengan menggunakan teknik observasi dan studi pustaka dari berbagai sumber yang ada relevansi dengan upaya peningkatan pemahaman bacaan siswa. Adapun hasilnya dapat disimpulkan bahwa metode SQ3R dapat meningkatkan pemahaman bacaan siswa. Hal ini terbukti siswa menjadi pembaca yang aktif dan terarah sehingga mereka dapat memahami isi bacaan yang tersirat dan yang tersurat secara efektif, adanya peningkatan kemampuan berkomunikasi siswa, dan perbedaan hasil belajar nilai rata-rata membaca bahasa Indonesia siswa kelas X SMA Mathla'ul Anwar Menes. Dengan demikian, metode SQ3R sangat tepat digunakan dalam pembelajaran membaca untuk meningkatkan pemahaman bacaan secara optimal. Namun demikian, mengingat adanya beberapa keterbatasan pada penelitian ini maka perlu dilakukan penelitian lanjutan dengan menggunakan data yang lebih besar dengan persentase observasi yang lebih tinggi untuk menjamin akurasi data.
\end{abstract}

Kata Kunci: pemahaman, bacaan, metode, $S Q 3 R$.

Correspoonding author: sobri_brian@yahoo.com 


\section{PENDAHULUAN}

Bahasa sebagai alat komunikasi, melalui bahasa manusia dapat berhubungan (komunikasi) saling berbagi pengalaman, saling belajar dari yang lain, dan dapat meningkatan intelektual. Mata pelajaran bahasa dan sastra Indonesia di SMA adalah program untuk mengembangkan pengetahuan, keterampilan berbahasa dan sikap positif terhadap bahasa Indonesia.

Pengalaman sehari-hari, sejak kecil hingga dewasa, bahasa seseorang mengalami perubahan. Bahasa itu mengalami perkembangan dari zaman ke zaman sesuai dengan perkembangan intelektual manusia dan kekayaan cipta karya manusia sebagai hasil kemajuan intelektual itu sendiri.

Peranan bahasa dalam dunia pendidikan memang besar, kegiatan berbahasa tidak dapat dilepaskan dari jenjang pendidikan manapun. Sangatlah sukar menentukan, pada jenjang pendidikan yang mana peranan tersebut lebih besar. Pemerintah menyadari pentingnya bahasa dalam pendidikan. Ditetapkannya mata pelajaran bahasa Indonesia sebagai mata pelajaran wajib di setiap jenjang pendidikan merupakan salah satu realisasi dari kesadaran tersebut. Menurut Tarigan (1987:1) menjelaskan bahwa "Tujuan pengajaran bahasa Indonesia adalah pembelajar memiliki keterampilan dalam setiap aspek kemampuan berbahasa, yaitu (1) keterampilan menyimak, (2) keterampilan berbicara, (3) keterampilan membaca, dan (4) keterampilan menulis. Dari keempat aspek keterampilan berbahasa tersebut, kemampuan membaca dan menulis merupakan kemampuan yang sangat penting dalam kehidupan kita pada masa lalu, dan lebih-lebih pada masa sekarang dan masa yang akan datang (Rusyana, 1984:189).

Membaca sebagai salah satu aspek keterampilan berbahasa memiliki peranan sangat penting bagi peningkatan kualitas kehidupan manusia. Dalam dunia pendidikan, peranan membaca sangat dominan karena dengan membaca para siswa akan mampu mengembangkan diri, menggali pengetahuan secara individu, dan mencari informasi yang ingin diketahui dan dibutuhkan. Pentingnya membaca bagi para siswa tercermin pada pendapat Rusyana (1984:189) yang mengatakan, "Kemampuan membaca merupakan kemampuan yang sangat penting bagi kita di masa lalu, dan lebih-lebih di masa sekarang, dan yang akan datang”. Seorang pembaca perlu pemahaman yang cukup untuk mengerti isi bacaan. Hal ini didukung pendapat Grellet (1991:3) yang mengatakan, "Mengerti suatu teks bacaan tidak hanya sekedar mengerti apa yang ada, tetapi lebih dalam lagi, yakni diperlukan pemahaman”. 
Standar kompetensi mata pelajaran bahasa Indonesia untuk SMA berorientasi pada hakikat pembelajaran bahasa, bahwa belajar bahasa adalah belajar berkomunikasi. Oleh karena itu, pembelajaran bahasa Indonesia diarahkan untuk meningkatkan kemampuan siswa untuk berkomunikasi dalam bahasa Indonesia, baik secara lisan maupun tertulis (KTSP, 2006:1). Standar kompetensi ini dimaksudkan agar siswa siap mengakses situasi multiglobal lokal yang berorientasi pada keterbukaan dan kemasadepanan. Adapun tujuan pembelajaran keterampilan membaca mata pelajaran bahasa Indonesia di SMA diarahkan agar siswa terbuka terhadap beraneka ragam informasi yang hadir di sekitar kita dan dapat menjaring yang berguna, belajar menjadi diri sendiri, dan siswa menyadari akan eksistensi budayanya.

Namun, berdasarkan kenyataan di lapangan bahwa tujuan pembelajaran membaca bahasa Indonesia di SMA seperti di atas belum tercapai secara optimal. Kenyataan menunjukkan tidak sedikit siswa yang mengalami kesulitan dalam memahami bentuk, makna, dan fungsi kalimat serta penggunaannya untuk berbagai tujuan, keperluan, dan keadaan. Hal ini terlihat dari Standar Ketuntasan Belajar Minimal (SKBM) mata pelajaran bahasa Indonesia siswa kelas X SMA Mathla'ul Anwar Menes tahun pelajaran 2017/2018 masih rendah yakni hanya 65. Untuk mengkaji rendahnya pemahaman bacaan bahasa Indonesia siswa, perlu dilihat faktor-faktor yang mempengaruhinya. Berdasarkan pengamatan penulis dan dua orang guru bahasa Indonesia terhadap siswa SMA Mathla'ul Anwar Menes, diduga faktor-faktor dominan yang menyebabkan rendahnya kemampuan pemahaman bacaan bahasa Indonesia siswa adalah rendahnya penguasaan struktur kalimat dan pengetahuan kebahasaan lainnya yang siswa kuasai. 
Faktor lain yang diduga menjadi penyebab rendahnya pemahaman bacaan bahasa Indonesia siswa adalah kurangnya tepatnya metode pembelajaran yang digunakan oleh guru. Ada banyak metode membaca yang ditawarkan ilmuwan.Tiap-tiap metode memiliki kelebihan dan kekurangannya. Oleh karena itu, guru harus cermat memilih metode membaca yang diyakini akan memberikan hasil belajar yang optimal, salah satunya adalah metode SQ3R. Metode SQ3R memberikan strategi yang diawali dengan membangun gambaran umum tentang bahan yang dipelajari, menumbuhkan pertanyaan dari judul dan dilanjutkan dengan membaca untuk mencari jawaban dari pertanyaan. Metode membaca SQ3R terdiri dari lima tahapan proses yaitu: survey, question, read, recite, review. Hasil pembelajaran siswa dengan menggunakan SQ3R dapat diharapkan memuaskan, karena dengan metode ini siswa menjadi pembaca aktif dan terarah langsung pada intisari atau kandungan-kandungan pokok yang tersirat dan tersurat dalam teks.

Berdasarkan latar belakang masalah yang telah dikemukakan di atas, maka masalah penelitian ini dirumuskan sebagai berikut, "Apakah metode SQ3R dapat meningkatkan pemahaman bacaan bahasa Indonesia siswa?". Adapun tujuan penelitian ini adalah ingin mengetahui efektivitas metode SQ3R dalam upaya meningkatkan pemahaman bacaan bahasa Indonesia siswa. Sedangkan manfaat penelitian ini diharapkan dapat memberikan informasi tentang efektivitas metode SQ3R dalam meningkatkan pemahaman bacaan bahasa Indonesia siswa. Informasi tersebut sangat berguna untuk guru bahasa Indonesia dan pemerintah serta pihak-pihak yang terkait karena selama ini tingkat pemahaman bacaan bahasa Indonesia siswa masih rendah.

Penelitian ini dilakukan dengan harapan dapat berguna bagi guru bahasa Indonesia dalam mengembangkan dan menentukan metode pembelajaran membaca yang tepat sehingga tujuan pembelajaran dapat tercapai secara optimal. Disamping itu, hasil penelitian ini diharapkan dapat digunakan oleh para siswa sebagai motivator dalam mengembangkan pemahaman bacaan bahasa Indonesia.

Selanjutnya, hasil penelitian ini diharapkan dapat memperkaya khasanah ilmu khususnya mengenai pemahaman bacaan bahasa Indonesia dan kaitannya metode pembelajaran membaca. Bagi para peneliti, hasil penelitian ini dapat digunakan sebagai landasan untuk mengadakan penelitian lebih lanjut yang lebih luas dan dalam, khususnya mengenai variabel yang diteliti maupun variabel yang lebih kompleks dalam mengembangkan pemahaman bacaan bahasa Indonesia siswa. 


\section{Hakikat Pemahaman Bacaan}

Chapman dan Czerniewska (1994:71-73) mengemukakan, "Pemahaman adalah proses kognitif yang menyertakan unsur impresi, persepsi, dan konseptualisasi. Untuk memperoleh pemahaman ketika membaca diperlukan pengetahuan awal yang berhubungan dengan kebahasaan dan juga topik bacaan". Yang dimaksud dengan persepsi adalah pemerolehan kata-kata, hasil decoding, dan melalui mata. Dalam persepsi terdapat pengertian (understanding), pemahaman (comprehension), dan pengorganisasian (organizing). Dengan demikian, makna atau pemahaman diperoleh tidak hanya melalui makna tertulis tetapi juga melalui situasi, kondisi, perhatian, dan atau buah pikiran yang telah ada dalam pikiran pembaca saat itu. Konseptualisasi adalah ketika persepsi tertentu dapat dikategorikan pada suatu kategori atau grup tertentu sehingga akan mendukung proses membaca selanjutnya, yaitu berfikir abstrak dan berpikir secara umum. Jadi, singkatnya proses pemahaman ketika membaca itu terdiri dari tiga, yaitu impresi, persepsi dan konseptualisasi.

Clark and Clark (1987:43) mendefinisikan Comprehension (pemahaman) sebagai proses pembentukan interpretasi atau pembentukan pengertian. Lebih lanjut diungkapkan bahwa proses pemahaman dibedakan menjadi dua yaitu contruction process dan utilization process. Proses pertama adalah pembentukan pengertian yang berdasarkan atas kalimat-kalimat yang diperoleh dari bacaan. Sedangkan proses kedua adalah proses bagaimana pengertian yang telah dibentuk itu dipakai sebagai tindak lanjut (aplikasi) dari pengertian yang diperoleh. 
Mackey (1985:127) mengatakan "Pemahaman adalah penafsiran (interpretation) dan harapan (expectancy)". Penafsiran terhadap apa yang diperoleh dari tulisan yang dibaca dan harapan untuk menemukan dan menggunakan hal-hal yang ditemukan dalam bacaan tersebut. Untuk dapat memperoleh pemahaman yang memadai, pembaca dituntut untuk benar-benar mengerti atau mengetahui dan dapat menafsirkan bentuk-bentuk bahasa tulis secara tepat dan benar. Kemudian Chapman dan Szerniewska (1994:69) menyebutkan "Tiga tingkat kategori pemahaman, yaitu pemahaman makna literal, pemahaman makna inferensial, dan pemahaman analitis sintesis". Pemahaman makna literal diperoleh melalui urutan kata makna menurut aturan tata bahasa, yaitu urutan kata dalam kalimat. Kemudian makna yang ditimbulkan oleh susunan kalimat dalam paragraf dan dalam teks secara keseluruhan. Pemahaman pada taraf ini juga tentunya tanpa mengenyampingkan perlunya memiliki pengetahuan yang berhubungan dengan apa yang sedang dibaca. Pemahaman inferensial adalah pemahaman makna yang tidak tertulis secara tersurat tapi tersirat. Sedangkan pemahaman analitis sintesis adalah pemahaman melalui proses analisis dan sintesis.

Beberapa pendapat para ahli di atas, maka yang dimaksud dengan pemahaman dalam penelitian ini adalah proses kognitif yang membentuk pengertian atau interpretasi berdasarkan atas kalimat-kalimat yang diperoleh dari bacaan atau teks.

Bacaan merupakan deretan kalimat-kalimat yang tersusun rapi dalam teks bacaan. Grellet (1991:6) mengemukakan "Teks merupakan kalimat-kalimat yang disatukan menurut suatu tema tertentu untuk memberikan makna menurut struktur kalimat dan makna menurut struktur teks secara keseluruhan. Selanjutnya, Nunan (1995:21-22) mengatakan "Teks (bacaan) adalah informasi tertulis berupa sekumpulan kalimat-kalimat lepas yang digabungkan secara koherensi". 
Berdasarkan uraian di atas, maka yang dimaksud dengan bacaan dalam penelitian ini adalah sekumpulan informasi tertulis berupa teks pendek yangmerupakan bagian dari teks lengkap dan memiliki makna tekstual tersendiri yang utuh. Sedangkan yang dimaksud dengan bacaan bahasa Indonesia adalah teks bacaan yang ditulis dalam bahasa Indonesia. Selanjutnya, pendapat yang membahas mengenai pemahaman bacaan dikemukakan oleh Lado (1987:223), "Pemahaman bacaan adalah aktivitas pemahaman arti dalam suatu bahasa melalui tulisan atau bacaan. Apabila diperhatikan batasan Lado tersebut menekankan kepada dua hal pokok, yaitu bahasa dan simbol grafis. Hanya orang yang telah menguasai bahasa dan simbol grafis yang dapat melakukan pemahaman bacaan sebab informasi tersebut disajikan oleh penulis melalui bacaan.

Rivers (1981:261) mengemukakan. "Seseorang dikatakan memiliki pemahaman bacaan yang dibacanya jika ia dapat menarik kesimpulan dari isi teks yang ditulis secara koherensi". Hal ini berarti bahwa pembaca memiliki kemampuan memahami makna teks bacaan sesuai dengan yang dimaksud penulis.

Berkaitan dengan proses membaca untuk mencapai pemahaman dijelaskan oleh Soedarso (1988:14) bahwa "Proses tersebut terdiri dari proses pemahaman kata dan kalimat yang sesuai dengan konteksnya, menarik kesimpulan dari keterangan yang ditulis secara inferensial baik melalui Skimming maupun scanning". Pemahaman kata yang dimaksudkan disini adalah bagaimana pembaca memahami kata sesuai dengan konteks yang ada dalam teks bacaan yang dibaca. Sedangkan pemahaman kalimat maksudnya adalah bagaimana pembaca memperoleh makna kata-kata yang terdapat dalam kalimat menurut konteksnya. Melalui skimming, pembaca dapat membaca cepat untuk memperoleh kesimpulan makna keseluruhan teks secara umum dan melalui scanning, pembaca dapat memperhatikan kata-kata tertentu atau melewati kata-kata tertentu yang dianggap tidak terlalu penting unruk memperoleh pemahaman informasi yang ingin diperoleh dari teks yang dibaca. 
Proses membaca, seorang pembaca harus cepat menemukan ide pokok yang terdapat dalam bacaan tersebut. Menurut Soedarso (1988:14) menemukan ide pokok suatu paragraf atau bacaan adalah kunci untuk mengerti apa yang kita baca. Apabila ide pokok telah dikuasai, maka detailnya dapat mudah dikenali. Oleh sebab itu, apabila membaca teks atau buku sebaiknya pembaca harus cepat menemukan ide pokoknya. Apabila ide pokoknya atau sentralnya telah ditemukan maka detailnya dapat mudah ditelusuri. Kesalahan umum yang dapat mengakibatkan kegagalan pemahaman bacaan yang kita temui selama ini adalah pembaca yang terlalu menekuni detail bacaan sehingga kehilangan ide sentralnya.

Memahami teks bacaan bagi sebagian siswa merupakan hal yang sulit. Kesulitan pemahaman bacaan tidak hanya disebabkan oleh kurangnya minat, motivasi, penguasaan struktur kalimat, kemampuan berpikir atau rumitnya suatu ide tetapi juga dapat disebabkan oleh kurang siapnya siswa membaca atau menerima materi pengajaran membaca itu sendiri. Kemampuan siswa menerima materi pelajaran lanjutan akan bergantung pada penguasaan siswa pada materi pelajaran pendukung sebelumnya.

Proses pembelajaran membaca, tak lepas dari penggunaan tes untuk mengetahui pemahaman siswa pada bacaan yang dibacanya. Pertanyaanpertanyaan yang diajukan dalam tes pemahaman bacaan dapat disesuaikan dengan tingkat pemahamannya. Rubin (1982:207-208) megemukakan “Terdapat empat kategori pemahaman yaitu pemahaman literal, interprestasi, membaca, dan membaca kreatif'. 
Dijelaskan bahwa pemahaman literal (arti kata) mewakili kemampuan membaca suatu tipe pemahaman tingkat yang lebih rendah (low-level type of understanding) dengan hanya menggunakan informasi yang dinyatakan secara eksplisit. Kategori ini menuntut suatu tingkat keterampilan-keterampilan berpikir yang lebih rendah dibanding dengan ketiga tingkat lainnya. Menjawab pertanyaan-pertanyaan pemahaman literal secara sederhana menuntut bahwa pembaca hanya mengulang apa yang disebut dalam bacaan. Interpretasi merupakan langkah selanjutnya dalam hirarki berpikir. Keterampilan ini menuntut suatu tingkat berpikir yang lebih tinggi karena pertanyaan-pertanyaan dikonsentrasikan pada jawaban-jawaban yang tidak secara langsung dinyatakan dalam wacana tetapi yang terkandung di dalamnya. Untuk menjawab pertanyaan- pertanyaan pada tingkat interaktif seperti ini pembaca harus memiliki kemampuan pemecahan masalah dan mampu berbuat pada berbagai tingkat abstraksi. Membaca kritis melibatkan evaluasi, pembuatan penilaian pribadi terhadap ketepatan, nilai, dan kebenaran tentang apa yang dibaca. Agar mampu membuat penilaian, seorang pembaca harus mampu mengumpulkan, menerjemahkan, mengaplikasikan, menganalisis, dan membuat sintesis atau informasi. Membaca kritis melibatkan beberapa keterampilan berupa kemampuan membedakan antara fakta dan opini, kemampuan membedakan antara fantasi dengan realitas, serta kemampuan mencamkan atau memperhatikan teknik-teknik propaganda. Sedangkan membaca kreatif memanfaatkan keterampilan-keterampilan berpikir lancar di luar dari kreatif, pembaca berusaha sampai pada solusi-solusi baru atau alternatif terhadap apa yang disajikan oleh penulis. 
Berkaitan dengan empat aspek pemahaman yang dikemukakan oleh Rubin tersebut, Burns dkk. (1984:183-198) memberikan pandangannya sebagai berikut : (1) Pemahaman literal adalah pemahaman terhadap informasi yang dinyatakan secara eksplisit atau tertulis dalam bacaan. Faktor-faktor yang dapat mendukung tercapainya pemahaman literal ini adalah bila pembaca mampu mengidentifikasikan pokok-pokok pikiran, contoh-contoh, hubungan sebab akibat, atau rangkaian peristiwa yang dinyatakan langsung oleh penulis dalam bacaan; (2) Pemahaman interpretative adalah pemahaman terhadap informasi yang tidak dinyatakan secara eksplisit dalam bacaan, atau pemahaman berdasarkan kesimpulan-kesimpulan yang dibuat pembaca berdasarkan bacaan yang ada. Faktor-faktor yang dapat mendukung tercapainya pemahaman interpretatif adalah bila pembaca mampu menyimpulkan hal-hal yang tidak secara eksplisit dinyatakan dalam bacaan, misalnya pokok-pokok pikiran yang ada dalam bacaan, adanya hubungan sebab akibat, kata-kata yang dihilangkan, serta mampu mendeteksi maksud penulis dalam penulisan bahan bacaan yang ada; (3) Pemahaman kritis adalah pemahaman yang didasarkan pada hasil evaluasi terhadap bahan bacaan, misalnya, apakah ide-ide yang dilontarkan penulis sesuai dengan norma-norma yang ada, sesuai dengan konteksnya, dan apakah sesuai dengan zamannya. Pembaca yang kritis harus selalu aktif, selalu bertanya, mencari fakta yang benar, dan menunda keputusan yang akan dibuat sampai ia membaca tuntas dan mempertimbangkan isi dari seluruh materi bacaan. Pemahaman kritis pada dasarnya bertumpu pada pemahaman literal dan pemahaman interpretatif, dan kemampuan untuk memahami ide-ide yang tersembunyi merupakan faktor yang sangat penting; (4) Pemahaman kreatif adalah pemahaman yang menjangkau aspek-aspek di luar materi bacaan yang disajikan penulis. Pemahaman ini menuntut pembaca untuk selalu berpikir sewaktu membaca dan menggunakan imajinasinya.

Melihat pengkategorian pemahaman dalam memahami bacaan tersebut yang dikemukakan oleh beberapa ahli, ternyata memiliki beberapa kesamaan, yaitu pemahaman literal, pemahaman interpretatif, pemahaman kritis dan pemahaman kreatif. Keempat pemahaman inilah yang akan digunakan peneliti sebagai acuan dalam kisi-kisi penelitian ini. 
Pemahaman literal diperoleh apabila siswa dapat mengingat dan mengenali kembali kata-kata atau kalimat yang terdapat dalam bacaan, dan siswa dapat memahami informasi secara tersurat (eksplisit) dalam bacaan yang dibacanya. Pemahaman interpretatif diperoleh apabila siswa dapat memahami informasi secara tersirat (implisit) maksudnya memahami makna yang tidak tertulis, siswa dapat membuat kesimpulan berdasarkan bacaan, siswa dapat menganalisis beberapa informasi dari bacaan, dan siswa dapat mengorganisasikan informasi-informasi yang diperoleh dari bahan bacaan. Pemahaman kritis diperoleh apabila siswa dapat memberikan penilaian pada bacaan yang dibaca.

Sedangkan Pemahaman kreatif diperoleh apabila siswa dapat mengapresiasikan bacaan yang telah dibaca.

Penelitian ini, yang dimaksud dengan bacaan adalah sekumpulan informasi tertulis berupa teks pendek yang merupakan bagian dari teks lengkap dan memiliki makna tekstual tersendiri. Bacaan bahasa Indonesia yang dimaksud disini adalah teks bacaan tersebut menggunakan teks bacaan yang ditulis dalam bahasa Indonesia. Tolak ukur pemahaman bacaan siswa yang digunakan dalam penelitian ini menggunakan empat aspek, yaitu pemahaman literal dan pemahaman interpretatif. Kedua aspek inilah yang akan dijadikan penentu baik tidaknya pemahaman bacaan bahasa Indonesia siswa kelas X SMA Mtahla'ul Anwar Menes-Pandeglang-Banten yang dijadikan sampel penelitian.

Berdasarkan uraian di atas dan kerangka teoritis sebelumnya, maka yang dimaksud dengan pemahaman bacaan bahasa Indonesia dalam penelitian ini adalah kecakapan kognitif seseorang dalam memahami makna bacaan bahasa Indonesia baik yang tersurat maupun yang tersirat yang meliputi pemahaman literal dan pemahaman interpretatif.

\section{Hakikat Metode SQ3R}

Kamus Besar Bahasa Indonesia (1995:652) menyebutkan "Metode adalah cara yang teratur dan terpikir baik-baik untuk mencapai maksud" atau "Cara kerja yang bersistem untuk memudahkan pelaksanaan suatu kegiatan guna mencapai tujuan yang ditentukan". Berdasarkan pengertian tersebut, maka yang dimaksud dengan metode dalam penelitian ini adalah cara teratur untuk mencapai tujuan pembelajaran membaca yang meliputi pemahaman literal dan pemahaman interpretatif. 
Banyak metode membaca yang ditawarkan para ahli, namun pada penelitian ini penulis akan membahas salah satunya yakni metode SQ3R. Metode SQ3R memberikan strategi yang diawali dengan membangun gambaran umum tentang suatu bahan yang dipelajari, menumbuhkan pertanyaan dari judul, dan dilanjutkan dengan membaca untuk mencari jawaban dari pertanyaan. Membaca dengan metode SQ3R terdiri atas lima proses yaitu : Survey atau meninjau, Question atau bertanya, Read atau membaca, Recite atau menuturkan, dan Review atau mengulang. (http//suarapelajarindonesia.wordpress.com/2007/08/01) Brown (2001:315) mengatakan,

One effective series of procedures for approaching a reading text has to come labeled the SQ3R technique, a process consiting of the following five steps: Survey, skim the text for an overview of main ideas; Question, the reader asks questions about what he or she wishes to get out of the text; Read, read the text while looking for answers to the previousely formulated questions; Recite, reprocess the sailent points of the text through oral or written language; Review, assess the importance of what one has just read and incorporate it into long-term associations.

Maksud dari ungkapan di atas adalah satu rangkaian efektif dari prosedur pendekatan membaca sebuah teks telah dikenal dengan sebuah teknik SQ3R yaitu sebuah proses yang terdiri dari lima tahapan sebagai berikut: Survey, membaca secara skimming teks untuk melihat kembali ide pokoknya; Question, pembaca mengajukan pertanyaan-pertanyaan mengenai apa yang dia inginkan dalam memahami teks tersebut; Read, bacalah teks ketika mencari jawaban untuk pertanyaan yang dirumuskan sebelumnya; Recite, memproses kembali poin-poin penting dari teks melalui bahasa lisan maupun tulisan; Review, menilai hal-hal penting dari apa yang telah seseorang baca dan terlibat (ingat) dalam waktu jangka panjang. 
Syah (2006:130) mengemukakan pendapatnya tentang metode SQ3R sebagai berikut : Kiat yang secara spesifik dirancang untuk memahami isi teks disebut metode SQ3R yang dikembangkan oleh Francis P. Robinson di Universitas Negeri Ohio Amerika Serikat. Metode ini bersifat praktis dan dapat diaplikasikan dalam berbagai pendekatan belajar. SQ3R pada prinsipnya merupakan singkatan langkah-langkah mempelajari teks yang meliputi : Survey, maksunya memeriksa atau meneliti atau mengidentifikasi seluruh teks; Question, maksudnya menyusun daftar pertanyaan yang relevan dengan teks; Read, maksudnya membaca teks secara aktif untuk mencari jawaban atas pertanyaan- pertanyaan yang telah tersusun; Recite, maksudnya menghafal setiap jawaban yang telah ditentukan; Review, maksudnya meninjau ulang seluruh jawaban atas pertanyaan yang tersusun pada langkah kedua dan ketiga.

Sobur (2003:253) mengemukakan bahwa, "Metode SQ3R merupakan kependekan dari lima tugas yang harus kita hadapi atau kita lakukan: survey (menyelidiki), question (bertanya), read (membaca), recite (menceritakan kembali), dan review (mengulang)".

Berdasarkan pendapat para ahli di atas, maka yang dimaksud dengan SQ3R dalam penelitian ini adalah strategi memahami test bacaan atau teks yang terdiri dari langkah-langkah: Survey, Questions, Read, Recite, dan Review. Syah (2006:131) menjelaskan langkah-langkah metode SQ3R adalah sebagai berikut 
Pertama, dalam melakukan aktivitas survey, perlu membantu dan mendorong siswa untuk memeriksa atau meneliti secara singkat seluruh struktur teks. Tujuannya adalah agar siswa mengetahui panjangnya teks, judul bagian (heading) dan judul subbagian (sub-heading), istilah dan kata kunci, dan sebagainya. kedua, guru sebaiknya memberi petunjuk atau contoh kepada para siswa untuk menyusun pertanyaan-pertanyaan yang jelas, singkat, dan relevan dengan bagian-bagian teks yang telah ditandai pada langkah pertama. Jumlah pertanyaan bergantung pada panjang-pendeknya teks dan kemampuan siswa dalam memahami teks yang sedang dipelajari. ketiga, guru menyuruh siswa membaca secara aktif dalam rangka mencari jawaban atas pertanyaanpertanyaan yang telah tersusun. Dalam hal ini, membaca secara aktif juga berarti membaca yang difokuskan pada paragraf-paragraf yang diperkirakan mengandung jawaban- jawaban yang diperkirakan relevan dengan pertanyaan tadi. keempat, seyogianya guru menyuruh menyebutkan lagi jawaban-jawaban atas pertanyaan yang telah tersusun. Latihlah siswa untuk tidak membuka catatan jawaban. Jika sebuah pertanyaan tak terjawab, siswa tetap disuruh menjawab pertanyaan berikutnya. Demikian seterusnya, hingga seluruh pertanyaan, termasuk yang belum terjawab, dapat diselesaikan dengan baik dan kelima, pada langkah terakhir (review) guru seyogianya menyuruh siswa meninjau ulang seluruh pertanyaan dan jawaban secara singkat.

Berdasarkan pendapat para ahli di atas, maka penulis dapat menyimpulkan bahwa alokasi waktu yang diperlukan untuk memahami sebuah teks dengan metode SQ3R, mungkin tidak banyak berbeda dengan mempelajari teks secara biasa (tanpa metode SQ3R). namun, hasil pembelajaran siswa dengan menggunakan SQ3R dapat diharapkan lebih memuaskan, karena dengan metode ini siswa menjadi pembaca aktif dan terarah langsung pada intisari atau kandungan-kandungan pokok yang tersirat dan tersurat dalam teks.

Sobur (2003:253) menjelaskan langkah-langkah metode SQ3R adalah sebagai berikut :

1) Survey, sebelum mulai membaca, perhatikan judul dan rangkuman bab (jika ada) untuk menemukan persoalan bab tersebut. Hal ini akan memberi pembaca kerangka berpikir yang bisa digunakan untuk mengatur bahan yang dibaca. Sebelum melanjutkan langkah pastikan bahwa pembaca mengerti tujuan bab itu dan apa yang hendak diajarkan. 
2) Questions, pada tahap ini pembaca melihat kembali judul bab, ubah menjadi pertanyaan, dan tulislah pertanyaan tersebut dengan merumuskan pertanyaan, pembaca meningkatkan keingintahuannya dan mengubahnya menjadi tujuan yang bertujuan yaitu tugas untuk menjawab pertanyaan tersebut.

3) Read, pada tahap ini pembaca membaca bagian bab di bawah subjudul untuk mencari jawaban pertanyaan. Dengan cara ini, pembaca harus menggali bahan, aktif mencari hal-hal penting. Kunci tipe pembaca adalah selektif. Membaca hendaknya tidak merupakan suatu perbuatan yang pasif, melainkan berupa perbuatan aktif untuk mencari jawaban atas pertanyaan-pertanyaan yang telah dibuat.

4) Recite, setelah menyelesaikan bagian bab tersebut, jangan melihat buku dan ceritakan kembali kepada diri sendiri melalui ingatan (diucapkan dengan keras jika mungkin) jawaban pertanyaannya. Gunakan kata-kata sendiri dan beri contoh. Selanjutnya, buka kembali lembaran tempat menulis pertanyaan dan buatlah jawaban dengan beberapa kata kunci. Paksakan untuk membuat catatan tersebut sesingkat mungkin (jika tidak dapat menjawab pertanyaan, lihat kembali bahannya sehingga pembaca dapat menjawabnya). Langkah menceritakan kembali ini adalah sangat penting bagi "pemasukan" bahan tersebut ke dalam otak, dan

5) Review, setelah menyelesaikan bab ini, atau tugas harian di dalamnya, simak sebentar catatan ulangan tentang hal-hal yang penting dan simpulkan hubungannya satu dengan lainnya. Pastikan pembaca mengerti arti kata-kata kunci. Kemudian, untuk tiap pertanyaan dan jawaban dalam catatan pembaca, tutup kata-kata kuncinya, baca pertanyaan-pertanyaannya, berilah jawaban. Mengulang ini menolong pembaca tidak cepat lupa, yaitu lupa apa yang baru saja dipelajari. Setelah itu ulangi bahan tersebut secara berkala agar terhindar dari lupa secara berangsur-angsur.

Berdasarkan pendapat para ahli di atas, maka penulis dapat menyimpulkan bahwa metode SQ3R sangat membantu mengingat dan menyimpulkan isi sebuah teks. Secara singkat langkah-langkah metode SQ3R adalah: pikirkan apa yang sedang kita baca, masukkan dalam pikiran, dan hubungkan hal tersebut dengan apa yang telah kita ketahui. Langkah-langkah ini diharapkan pembaca akan memahami teks secara mendalam. 


\section{METODOLOGI}

Adapun tujuan akhir yang hendak dicapai dalam penelitian ini adalah ingin mengetahui efektivitas metode SQ3R dalam upaya meningkatkan pemahaman bacaan siswa serta diharapkan dapat memberikan informasi tentang efektivitas metode SQ3R dalam meningkatkan pemahaman bacaan siswa.

Pendekatan yang digunakan dalam penelitian ini adalah pendekatan kualitatif, Pendekatan kualitatif digunakan dalam penelitian ini bersifat subjektif atau tidak dapat dikontrol, dan pendekatan ini digunakan untuk mengindentifikasi dan memberikan metode membaca untuk siswa yang tepat berdasarkan teori dan kebutuhan. Selain dari itu, data penelitian dikumpulkan melalui observasi dan studi pustaka.

\section{HASIL DAN PEMBAHASAN}

Penelitian ini dimaksudkan untuk mengetahui bagaimana peningkatan kemampuan membaca siswa dengan menerapkan metode SQ3R. Untuk keperluan tersebut, penelitian ini dilakukan secara eksperimental pada siswa SMA Mathla'ul Anwar Menes-Pandeglang-Banten. Subjek populasinya adalah seluruh siswa SMA Mathla'ul Anwar Menes dengan sampelnya adalah seluruh siswa kelas X-1 sebanyak 40 orang. Seluruh siswa tersebut mendapatkan perlakuan cara membaca memakai metode SQ3R. Untuk lebih lengkapnya, penulis akan uraikan beberapa temuan tiap-tiap tahapan hasil pengamatan di dalam kelas. 


\section{Hasil Temuan pada Tahap Survey}

Tahapan ini diawali dengan guru meminta siswa untuk memperhatikan judul atau subjudul dan kalau ada rangkuman bab atau subbab. Kegiatan ini ditujukan untuk menemukan persoalan bab tersebut sebelum siswa mulai membaca. Pada saat penulis meminta siswa memperhatikan judul teks Recount yang diberikan, siswa sangat antusias ingin mengetahui informasi yang terkandung dalam teks. Langkah awal ini sangat membantu dan mendorong siswa untuk memeriksa atau meneliti secara singkat seluruh struktur teks, sehingga siswa mengetahui panjangnya teks, judul bagian (heading) dan judul subbagian (sub-heading), istilah dan kata kunci, dan sebagainya. Sebelum melanjutkan langkah berikutnya, penulis memastikan bahwa siswa mengerti tujuan apa yang hendak diajarkan. Melakukan penyelidikan sebaiknya tidak memakan waktu lebih dari satu menit. Dengan mempunyai gambaran mengenai pokok-pokok yang akan dipelajari, pembaca akan dapat membaca teks itu dengan lebih cepat dan juga pokok-pokok itu akan bisa dihubungkan satu sama lainnya dengan baik. Pada tahapan ini siswa menandai bagian-bagian tertentu dengan pensil, kertas, dan alat pembuat ciri seperti stabilo karena bagian-bagian penting yang akan dijadikan bahan pertanyaan, perlu ditandai untuk memudahkan proses penyusunan daftar pertanyaan pada langkah selanjutnya. Pada tahap ini siswa telah mengetahui ide umum dari bacaan jenis recount dengan jumlah kata 250 kata yang mereka akan baca.

\section{Hasil Temuan pada Tahap Question}

Pada tahap ini penulis memberikan petunjuk atau contoh kepada siswa untuk menyusun pertanyaan-pertanyaan yang jelas, singkat, dan relevan dengan bagian- bagian teks yang telah ditandai pada langkah pertama. Lalu, penulis meminta siswa menuliskan 10 butir pertanyaan yang relevan dengan teks bacaan yang diberikan karena penulis berpedoman bahwa jumlah pertanyaan bergantung pada panjang-pendeknya teks dan kemampuan siswa dalam memahami teks yang sedang dipelajari. Di samping itu, bacaan yang sedang dipelajari siswa berisi hal- hal yang belum mereka ketahui karena apabila latar belakang pengetahuan siswa tidak berhubungan dengan isi teks, maka perlu menyusun pertanyaan sebanyak- banyaknya. Pada tahap ini masing-masing siswa dapat membuat 10 pertanyaan sebagaimana yang dianjurkan oleh penulis. Alokasi waktu untuk membuat pertanyaan ini adalah 20 menit. 


\section{Hasil Temuan pada tahap Read}

Pada tahap ini guru meminta siswa membaca secara aktif dalam rangka mencari jawaban atas pertanyaan-pertanyaan yang telah tersusun. Adapun ungkapan yang digunakan penulis pada tahap ini adalah "Sekarang baca teks bagian demi bagian, lalu temukan jawaban atas pertanyaan-pertanyaan kalian itu selama membaca". "Ingat apa pertanyaan kalian?".

Berdasarkan pengamatan penulis, seluruh siswa membaca secara aktif. Mereka juga membaca dengan cara memfokuskan pada paragraf-paragraf yang diperkirakan mengandung jawaban-jawaban yang diperkirakan relevan dengan pertanyaan. Mereka membaca dengan sangat aktif untuk mencari jawaban atas pertanyaan-pertanyaan yang telah dibuat.

Setelah selesai, penulis mengecek apakah siswa dapat menemukan jawaban dengan tepat? Ternyata ada 3 orang siswa yang tidak dapat menemukan jawabannya. Oleh karena itu, penulis membantu menemukan jawabannya.

\section{Hasil Temuan pada Tahap Recite}

Setelah menyelesaikan seluruh bacaan yang menjadi tugas siswa, penulis mengetes daya ingat siswa atas jawaban-jawaban pertanyaan dengan cara meminta siswa menyebutkan kembali pertanyaannya dan mengemukakan jawabannya. Siswa dilarang membuka catatan jawaban. Jika sebuah pertanyaan tak terjawab, siswa tetap disuruh menjawab pertanyaan berikutnya. Demikian seterusnya, hingga seluruh pertanyaan, termasuk yang belum terjawab, dapat diselesaikan dengan baik.

Berdasarkan pengamatan penulis, seluruh siswa dapat mengungkapkan jawaban-jawaban atas pertanyaan-pertanyaan walaupun sesekali membuka catatan jawaban. Setiap siswa yang dapat mengungkapkan jawaban-jawaban atas pertanyaan-pertanyaan dengan benar tanpa membuka catatan, penulis memberikan acungan jempol dengan kata "very clever" atau "excellent.". 


\section{Hasil Temuan pada Tahap Review}

Pada tahap ini penulis meminta siswa menyimak sebentar catatan tentang hal-hal yang penting dan simpulkan hubungannya satu dengan lainnya. Pastikan siswa mengerti arti kata-kata kunci. Kemudian untuk tiap pertanyaan dan jawaban dalam catatan siswa, tutup kata-kata kuncinya, baca pertanyaanpertanyaannya, berilah jawaban. Pengulangan ini membantu siswa tidak cepat lupa apa yang baru saja dipelajari. Setelah itu ulangi bahan tersebut secara berkala agar terhindar dari lupa secara berangsur-angsur.

Berdasarkan pengamatan penulis, review ini sangat membantu siswa untuk menyempurnakan kerangka pemikiran dalam membangun suatu teks dan membangun daya ingat mereka untuk bahan bacaan tersebut. Proses ini dapat dilakukan dengan cara membaca ulang seluruh bacaan (teks), melengkapi catatan atau berdiskusi dengan teman-temannya. Cara ini akan lebih efektif dengan cara menjelaskan kepada temannya.

\section{PENUTUP}

Berdasarkan hasil dan pembahasan yang telah dikemukakan pada bagian sebelumnya, maka dapat disimpulkan bahwa metode SQ3R dapat meningkatkan pemahaman bacaan siswa. Hal ini terbukti siswa menjadi pembaca yang aktif dan terarah sehingga mereka dapat memahami isi bacaan yang tersirat dan yang tersurat secara efektif, adanya peningkatan kemampuan berkomunikasi siswa, dan perbedaan hasil belajar nilai rata-rata membaca bahasa Indonesia siswa kelas X-1 SMA Mathla'ul Anwar Menes.

Dengan demikian, metode SQ3R sangat tepat digunakan dalam pembelajaran membaca untuk meningkatkan pemahaman bacaan secara optimal. Namun demikian, mengingat adanya beberapa keterbatasan pada penelitian ini maka perlu dilakukan penelitian lanjutan dengan menggunakan data yang lebih besar dengan persentase observasi yang lebih tinggi untuk menjamin akurasi data. 
Berdasarkan kesimpulan yang telah diuraikan, maka dapat diajukan beberapa saran sebagai berikut. Pertama, agar metode SQ3R ini dapat berhasil dengan baik, maka jangan sesekali melompati setiap langkah yang ada. Setiap langkah dalam metode SQ3R bergantung pada satu atau langkah-langkah sebelumnya. Jika meninggalkan satu diantara langkah-langkah itu, akan mengurangi efektivitas metode ini. Kedua, dalam menilai kemampuan pemahaman bacaan siswa, sebaiknya guru mengadakan variasi bahan bacaan seperti menggunakan koran, majalah, brosur, artikel, bulletin, dan sejenisnya sebagai bahan bacaan yang mengandung informasi terkini.

\section{DAFTAR PUSTAKA}

Burns, Paul C. D. Roe, Betty, dan Elinor P. Ross. 1984. Teaching Reading in Today's Elementary Schools. Boston: Houghton Mifflin Company.

Brown, H. Doughlas. 2001. Teaching by Principles. New Jersey: Prentice Hall Regents.

Chapman, John and Pam Czerniewska, Pam. 1994. Reading from Process to Practice. London: Routledge \& Kegan Paul Ltd.

Clark, Herbert H. and Clark, Eve H. 1987. Psychology and Language: An Introduction to Psycholinguisticts. (New York: Harcourt Brace Jovanivich, Inc

Depdiknas. 2004. Kurikulum Pendidikan Menengah. Jakarta: Depdiknas. 2003. Kamus Besar Bahasa Indonesia. Edisi Ke-3. Jakarta: Balai Pustaka

Grellet, Francoise. 1991. Developing Reading Skills: Practical Guide to Reading Comprehension Exercises. Cambridge University Press.

Lado, Robert. 1987. Language Testing. London: Longman.

Mackey, William. Language Teaching Analysis. London: Longman Group, Ltd., 1965.

Mulyasa, E. 2006. Kurikulum Tingkat Satuan Pendidikan. Bandung: Remaja Rosdakarya.

Nunan, David. 1995. Language Teaching Methodology. Great Britain: Phoenix ELT.

Rivers, Wilga M. 1981. Teaching-Foreign Language Skills. (USA: The University of Chicago Press.

Rubin, Dorothy. 1982. Diagnosis and Corrections in Reading Instruction. (New York: Rinehart and Wiston).

Rusyana, Yus. 1984. Bahasa dan Sastra dalam Gamitan Pendidikan. Bandung: Diponegoro.

Sobur, Alex. 2003. Psikologi Umum. Bandung: CV. Pustaka Setia. 
Soedarso, 1988. Sistem Membaca Cepat dan Efektif. Jakarta: PT. Gramedia.

Syah, Muhibbin. 2006. Psikologi Pendidikan dengan Pendekatan Baru. Bandung: Remaja Rosdakarya.

Tarigan, Henry Guntur. 1987. Menulis Sebagai Suatu Keterampilan Berbahasa. Bandung: Angkasa.

\section{Lampiran : 1}

\section{Langkah-Langkah Pemodelan Pembelajaran dengan Penerapan Strategi Belajar SQ3R}

\begin{tabular}{|c|c|c|}
\hline Langkah-langkah & Tingkah Laku Guru & Aktivitas Guru \\
\hline $\begin{array}{l}\text { Langkah } 1 \\
\text { Survey }\end{array}$ & $\begin{array}{c}\text { a. Memberikan bahan bacaan kepada } \\
\text { siswa untuk dibaca. } \\
\text { b. Menginformasikan kepada siswa } \\
\text { bagaimana menentukan ide } \\
\text { pokok/tujuan pembelajaran yang } \\
\text { hendak dicapai. }\end{array}$ & $\begin{array}{l}\text { Membaca selintas dengan } \\
\text { cepat untuk menemukan ide } \\
\text { pokok/tujuan pembelajaran } \\
\text { yang hendak dicapai. }\end{array}$ \\
\hline $\begin{array}{l}\text { Langkah } 2 \\
\text { Question }\end{array}$ & $\begin{array}{l}\text { a. Menginformasikan kepada siswa } \\
\text { agar memperhatikan makna dari } \\
\text { bacaan. } \\
\text { b. Memberikan tugas kepada siswa } \\
\text { untuk membuat pertanyaan dari } \\
\text { ide pokok yang ditemukan dengan } \\
\text { menggunakan kata-kata apa, } \\
\text { mengapa, siapa dan bagaimana. }\end{array}$ & $\begin{array}{l}\text { a. Memperhatikan penjelasan } \\
\text { guru. } \\
\text { b. Menjawab pertanyaan yang } \\
\text { telah dibuatnya. }\end{array}$ \\
\hline $\begin{array}{l}\text { Langkah } 3 \\
\text { Read }\end{array}$ & $\begin{array}{l}\text { Memberikan tugas kepada siswa untuk } \\
\text { membaca dan menanggapi/menjawab } \\
\text { pertanyaan yang telah disusun } \\
\text { sebelumnya. }\end{array}$ & $\begin{array}{l}\text { Membaca secara aktif sambil } \\
\text { memberikan tanggapan } \\
\text { terhadap apa yang telah dibaca } \\
\text { dan menjawab pertanyaan } \\
\text { yang dibuatnya. }\end{array}$ \\
\hline $\begin{array}{l}\text { Langkah } 4 \\
\text { Recite }\end{array}$ & $\begin{array}{l}\text { Meminta siswa membuat inti sari dari } \\
\text { seluruh pembahasan pelajaran yang } \\
\text { telah dipelajari hari ini. }\end{array}$ & $\begin{array}{l}\text { a. Menanyakan dan menjawab } \\
\text { pertanyaan-pertanyaan. } \\
\text { b. Melihat catatan- } \\
\text { catatan/intisari yang telah } \\
\text { dibuat sebelumnya. } \\
\text { c. Membuat intisari dari } \\
\text { seluruh pembahasan. }\end{array}$ \\
\hline \multirow[t]{2}{*}{$\begin{array}{l}\text { Langkah } 5 \\
\text { Review }\end{array}$} & $\begin{array}{l}\text { a. Menugaskan siswa membaca } \\
\text { intisari yang dibuatnya dari rincian }\end{array}$ & $\begin{array}{l}\text { a. Membaca intisari yang } \\
\text { telah dibuatnya. }\end{array}$ \\
\hline & $\begin{array}{l}\text { ide pokok yang ada dalam } \\
\text { benaknya. } \\
\text { b. Meminta siswa membaca kembali } \\
\text { bahan bacaan, jika masih belum } \\
\text { yakin dengan jawabannya. }\end{array}$ & $\begin{array}{l}\text { b. Membaca kembali bahan } \\
\text { bacaan siswa jika masih } \\
\text { belum yakin akan jawaban } \\
\text { yang telah dibuatnya. }\end{array}$ \\
\hline
\end{tabular}




\section{Lampiran}

\section{$: 2$}

\section{Langkah-langkah Penerapan Pembelajaran Strategi SQ3R}

\begin{tabular}{|c|c|c|}
\hline No. & Aktivitas Guru & Aktivitas \\
\hline I. & $\begin{array}{c}\text { PENDAHULUAN } \\
\text { a. Memyampaikan tujuan pembelajaran } \\
\text { b. Mengaitkan pelajaran yang akan dipelajari } \\
\text { dengan pengetahuan awal siswa. } \\
\text { c. Memotivasi siswa. }\end{array}$ & $\begin{array}{l}\text { a. Dalam pelaksanaan KBM guru } \\
\text { menginformasikan tujuan } \\
\text { pembelajaran secara lisan, dan } \\
\text { menuliskan TPK yang akan dicapai. } \\
\text { b. Guru mengingatkan kembali materi- } \\
\text { materi sebelumnya yang relevan } \\
\text { dengan materi yang akan } \\
\text { disampaikan. } \\
\text { Guru memotivasi siswa dengan } \\
\text { memperlihatkan fenomena } \\
\text { tervisualisasi. Misalnya, dalam } \\
\text { mempelajari ekosistem guru } \\
\text { memperlihatkan sebuah akuarium } \\
\text { mini ekosistem (melalui charta) dan } \\
\text { menanyakan kepada siswa } \\
\text { komponen-komponen apa saja yang } \\
\text { terdapat pada gambar tersebut. }\end{array}$ \\
\hline II. & $\begin{array}{c}\text { KEGIATAN INTI } \\
\text { a. Mempresentasikan materi } \\
\text { b. Pemodelan strategi belajar SQ3R. } \\
\text { c. Pemberian latihan terbimbing. } \\
\text { d. Umpan balik. } \\
\text { e. Pemberian latihan mandiri. }\end{array}$ & $\begin{array}{l}\text { a. Sebelum pelaksanaan pengajaran } \\
\text { strategi belajar, guru } \\
\text { mempresentasikan sedikit gambaran } \\
\text { umum dari materi yang akan } \\
\text { dipelajari. } \\
\text { b. Guru memodelkan keterampilan } \\
\text { strategi belajar SQ3R langkah } \\
\text { perlangkah pada tiap-tiap tahapnya, } \\
\text { dengan memakai sedikit materi dari } \\
\text { bacaan. } \\
\text { c. Siswa di bawah bimbingan guru, } \\
\text { melakukan keterampilan strategi } \\
\text { belajar SQ3R, dengan mengerjakan } \\
\text { kertas kerja siswa. }\end{array}$ \\
\hline
\end{tabular}




\begin{tabular}{|c|c|c|}
\hline \multicolumn{1}{|c|}{} & $\begin{array}{c}\text { d. Pada tahap umpan balik, guru } \\
\text { memberikan beberapa pertanyaan } \\
\text { kepada siswa untuk mereka jawab. } \\
\text { Guru menunjuk beberapa siswa. }\end{array}$ \\
e. Guru memberikan latihan mandiri \\
III.
\end{tabular}

